Кристопчук М.С. ${ }^{1}$, Хітров I.О. ${ }^{1}$, Цьонь О.П. ${ }^{2}$, Почужевський О.Д. ${ }^{3}$

${ }^{1}$ Національний університет водного господарства та природокористування, Рівне, Україна;

${ }^{2}$ Тернопільський національний технічний університет імені Івана Пулюя, Тернопіль, Україна; ${ }^{3}$ Криворізький начіональний університет, Кривий Ріг, Украӥна

\title{
ДОСЛІДЖЕННЯ КООРДИНОВАНОГО УПРАВЛІННЯ ТРАНСПОРТНИМИ ПОТОКАМИ В ЦЕНТРАЛЬНІЙ ЧАСТИНІ МІСТА
}

\begin{abstract}
Проблеми, пов'язані з погіршенням функціонування вулично-дорожньої мережі суттєво впливають на роботу всього транспортного комплексу міста. Затримки транспорту в процесі руху, виникнення заторів, які характеризуються збільшенням часу на переміщення, погіршення транспортного обслуговування, підвищення рівня забруднення міського середовища внаслідок збільшення шкідливих викидів і підвищення рівня шуму, зростання кількості дорожньо-транспортних пригод свідчать про невідповідність пропускної здатності вулично-дорожньої мережі міст сучасному рівню автомобілізації. Найбільші труднощі з раціональною організацією дорожнього руху виникають на перехрестях вулиць, оскільки вони є «вузькими місцями» на вулично-дорожній мережі з погляду ефективного та безпечного обслуговування транспортних та пішохідних потоків. Для управління дорожнім рухом на перехрестях найчастіше використовують світлофорне регулювання, яке дає змогу підвищити безпеку дорожнього руху, скоротити затримки учасників дорожнього руху, зменшити споживання енергоресурсів та негативний вплив на довкілля, що, в свою чергу, має істотний вплив якість життя у містах.

Створюючи умови для оптимізації роботи регульованих перехресть потрібно враховувати технічний стан транспортних засобів, стан дорожнього покриття та технічні засоби регулювання дорожнього руху. Зменшення витрат часу на пересування, мінімізація фінансових і матеріальних витрат, забезпечення безпеки руху автомобілів і пішоходів, комфорт та зручність при пересуваннях $\epsilon$ основними вимогами до функціонування вулично-дорожньої мережі та транспортної інфраструктури. В багатьох випадках, інтенсивність руху транспортних засобів перевищує пропускну здатність вулично-дорожньої мережі, тому важливим $\epsilon$ питання підвищення ефективності іiі функціонування із найменшими капітальними фінансовими витратами.

У роботі розглянуто результати дослідження впливу координованого управління транспортними потоками в центральній частині міста Рівне на зниження транспортних затримок при проїзді перехресть транспортними засобами та запропоновано технічні рішення щодо підвищення безпеки дорожнього руху шляхом обладнання перехресть додатковими технічними засобами регулювання дорожнього руху.

Ключові слова: інтенсивність транспортних потоків, склад транспортного потоку, координоване управління, потік насичення, регульоване перехрестя, цикл світлофорного регулювання.
\end{abstract}

\section{ВСТУП}

Постійне зростання кількості міського транспорту неминуче призводить до збільшенням їх затримок на перехрестях доріг, збільшує транспортну втомлюваність, негативно впливає на довкілля.

Покращення організації дорожнього руху транспортної мережі міста можна досягти шляхом перерозподілу пропускної здатності перехресть, зменшення часу затримок транспорту, покращення режимів регулювання світлофорних об’єктів. Перспективним в цьому плані $\epsilon$ реалізація світлофорного регулювання за принципом «зеленої хвилі» на перехрестях доріг. Для координованого регулювання міста Рівне необхідно дослідити інтенсивність транспортних потоків та їх склад, пропускну здатність проїзної частини та режими роботи світлофорного об’єкта.

\section{АНАЛІЗ ЛІТЕРАТУРНИХ ДАНИХ ТА ПОСТАНОВКА ПРОБЛЕМИ}

Актуальність і необхідність досліджень режимів світлофорного підтверджено багатьма вітчизняними і закордонними вченими.

Дослідником О. М. Грицунем [1] описано залежність довжини черги рухомого складу від рівня завантаження смуг руху, вплив світлофорного регулювання на затримку руху транспорту і поведінку пішоходів.

Аналіз літературних джерел [2-7] свідчить про недоцільність застосування світлофорного регулювання вулично-дорожньої мережі нижчого рівня.

Необхідність застосування примусового світлофорного регулювання транспортних потоків детально описано в «Системології на транспорті. Організація дорожнього руху» [6].

При збільшені інтенсивності транспортних потоків і наближені значень, наведених у $[6,8]$, можна організувати рух транспортних засобів через перехрестя в одному рівні тільки застосувавши світлофорне регулювання. 
Запропоновано методи визначення тривалості фаз світлофорного регулювання шляхом оцінки довжини черги транспортних засобів (транспортних затримок), які виникли перед стоп-лінією [1115].

Науковцями Т. Метсон та У. Сміт [12] запропоновано визначення тривалості циклу світлофорного регулювання за додатковою транспортною затримкою

$$
\mathrm{T}_{\mathrm{L}}=\frac{3600 \sum_{k=1}^{\mathrm{i}} K_{k}}{3600-\sum_{k=1}^{i}\left(N_{\mathrm{T} 1}+N_{\mathrm{T} 2}\right) D_{k}},
$$

де $K_{k}$ - додаткова транспортна затримка кожного транспортного засобу в черзі, с./авт.;

$N_{\mathrm{T} 1}, N_{\mathrm{T} 2}-$ інтенсивність руху транспортних засобів за конфліктними напрямами, зв.од./год,

$i$ - кількість фаз циклу світлофорного регулювання.

Практичне застосування формули (1) обмежене, оскільки враховуються тільки додаткові затримки.

Запропонований Вебстером $[4,14,15]$ метод визначення тривалості циклів світлофорного регулювання враховує випадковий порядок прибуття транспортних засобів до контрольованого перехрестя

$$
\mathrm{T}_{ц}=\frac{1,5 \cdot \mathrm{T}_{n}+5}{1-\sum_{i=1}^{n} y_{i}},
$$

де $\mathrm{T}_{n}$ - сума проміжних тактів, с.;

$y_{i}$ - фазовий коефіцієнт $i$-тої фази регулювання;

$n$ - кількість фаз циклу регулювання.

В. В. Гілевич [8], розглядав моделі транспортних затримок на перехресті 3 жорсткими світлофорними циклами. Автором досліджено взаємозв'язок тривалості світлофорного циклу 3 технічним стан транспортних засобів.

Значення середньої затримки $(d)$ найчастіше визначають за формулою (3), яка грунтується на гіпотезі, що середня тривалість затримки дорівнює половині періоду протягом якого заборонено рух $[8,10,11]$, тобто

$$
d=\frac{\mathrm{T}_{\mathrm{L}}-t_{3}}{2}
$$

де $\mathrm{T}_{ц}$ - тривалість світлофорного циклу, с.;

$t_{3}-$ тривалість дозвільного сигналу світлофора, с.

При дослідженні ізольованих регульованих перехресть, приймається, що транспортні засоби які прибувають до них описуються випадковим процесом. Вебстер [11-15] запропонував формулу, яка враховує випадковий характер транспортних потоків

$$
d=\frac{\mathrm{T}_{\mathrm{L}}(1-\lambda)^{2}}{2(1-\lambda x)}+\frac{x^{2}}{2 N(1-x)}-0,65\left(\frac{\mathrm{T}_{\mathrm{L}}}{N^{2}}\right)^{\frac{1}{3}} x^{2+5 \lambda}
$$

де $\lambda$ - відношення тривалості зеленого сигналу світлофора до тривалості циклу;

$x$ - ступінь насичення напрямку руху;

$N$ - інтенсивність руху транспортних засобів досліджуваного напрямку, од./с.

Для покращення транспортної ситуації міста необхідно постійно реформувати вуличнодорожню мережу із зростанням кількості транспортних засобів, забезпечити умов для безперешкодного руху громадського транспорту [8-15]. Зрозуміло, що для міст 3 історично сформованою вулично-дорожньою мережею, враховувати всі ці чинники одночасно важко.

За критерій оптимізації світлофорного регулювання найчастіше приймають середню затримку транспортних засобів перед перехрестям [8-15]. Отриманий показник можна застосувати для визначення геометричних параметрів смуг руху перед перехрестям, оцінки екологічної складової транспорту [13], визначити економічну ефективність реалізованих заходів [8, 10, 11].

Ефективність світлофорного регулювання залежить від вибору оціночних критеріїв, які будуть реалізовані через визначення тривалості циклу роботи світлофорів [1-10]. В якості оцінки приймають швидкість руху транспортного потоку, довжину черги транспортних засобів перед перехрестям, характеристики дорожньої мережі, часові параметри проїзду перехресть.

Можливість раціонально змінювати режими світлофорного регулювання враховуючи дорожню ситуацію, є головною перевагою світлофорної сигналізації над іншими способами регулювання дорожнього руху.

\section{ЦІЛЬ ТА ЗАДАЧІ ДОСЛІДЖЕННЯ}

Ціль роботи - оцінка впливу технічних засобів організації дорожнього руху на регулювання інтенсивності транспортних потоків вулично-дорожньої мережі. Зниження транспортних затримок 
можливе за рахунок введення координованого управління транспортними потоками, з урахуванням їх інтенсивності та складу транспортного потоку.

Координування світлофорного регулювання сприяє підвищенню швидкості проїзду складних перехресть, іiі стабілізації; скорочує зупинки транспортних засобів перед перехрестями; вирівнює транспортні потоки; зменшує шкідливі викиди від діяльності транспорту в атмосферу.

\section{РЕЗУЛЬТАТИ ДОСЛІЖЕНЬ}

Місто Рівне розташоване в західній частині України - головний обласний центр Рівненської області. Чисельність жителів міста становить понад 246 тисяч при загальній площі в 63 км². Загальна протяжність автомобільних доріг Рівненській області становить понад 2009 км, серед яких 372 км міжнародного значення. Загальна кількість вулиць міста Рівне складає 442 з сумарною протяжністю 3 твердим покриття понад 300 км. Для повноцінного функціонування вулично-дорожньої мережа міста передбачено 8 мостів та 4 шляхопроводи, понад 70 світлофорних об'єктів. Для забезпечення потреб населення у пересуваннях містом функціонує мережа автобусного (28 маршрутів) і тролейбусного сполучення (10 маршрутів) із загальною кількість одиниць рухомого складу -345 .

В м. Рівне було проведено обстеження роботи світлофорних об'єктів та інтенсивності руху транспортних засобів на основних перехрестях. Склад транспортних потоків та їх інтенсивність представлено на рис. 1-3.

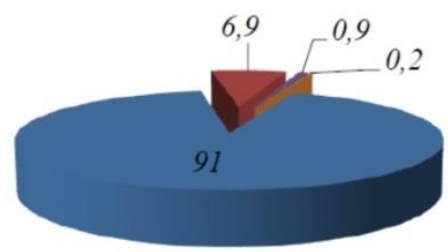

a)

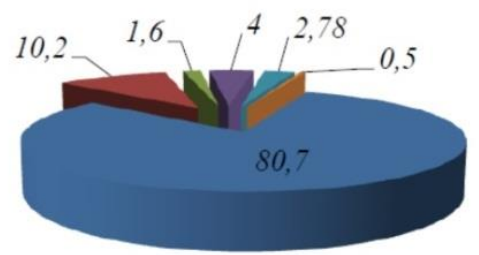

в)

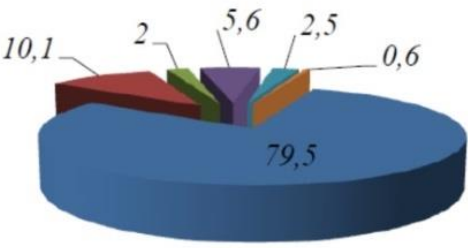

б)

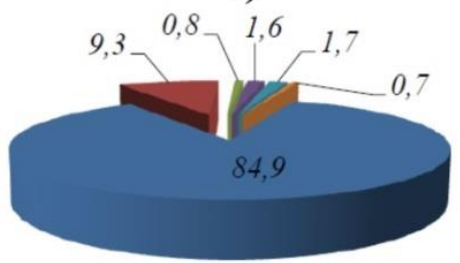

2)

Тип транспортного засобу в транспортному потоці:

\begin{tabular}{|c|c|}
\hline = Легковий & = Aвтобус міськй \\
\hline = Вантажний & = Тролейбус \\
\hline
\end{tabular}

Рисунок 1 - Склад транспортного потоку (\%) на перехрестях:

а) вул. Проспект Миру - вул. Міцкевича; б) вул. Соборна - вул. В. Чорновола - вул. Міцкевича;

в) вул. Соборна - вул. Княгині Ольги - вул. Князя Володимира; г) вул. Соборна - вул. Дубенська

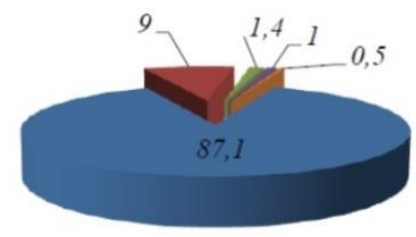

a)

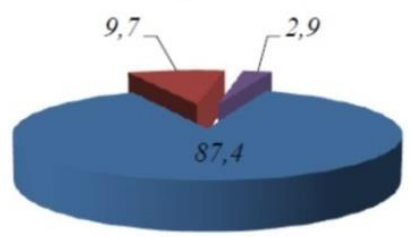

B)

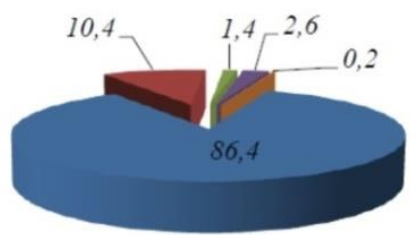

б)

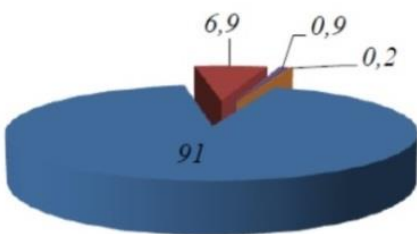

2)

Тип транспортного засобу в транспортному потоці:

- Легковий - Автобус місьюй

" Вантажний

"Тролейбус

" Велосипед

Рисунок 2 - Склад транспортних потоків (\%) на перехрестях Проспект Миру - вул. Набережна (а), Проспект Миру - вул. Шевченка (б), Проспект Миру - вул. Симона Петлюри (в) та Проспект Миру вул. Міцкевича (г) 


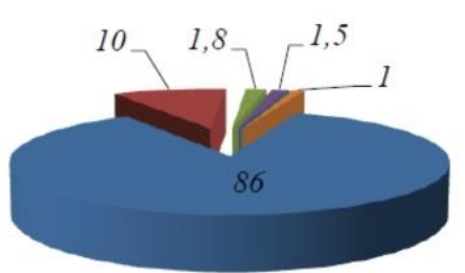

a)

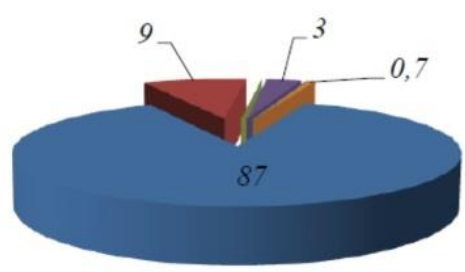

б)

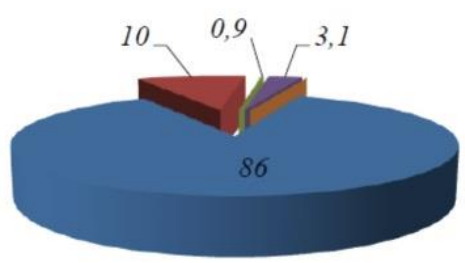

в)

Тип транспортного засобу в транспортному потоці:

\section{- Легковий}

в Вантажний
- Автобус міський
- Тролейбус

$$
\begin{aligned}
& \text { - Автобус } \\
& \text { Велосипед }
\end{aligned}
$$

Рисунок 3 - Склад транспортних потоків (\%) на ділянках вулиці Проспект Миру:

а) від перехрестя Проспект Миру - вул. Набережна до перехрестя Проспект Миру - вул. Шевченка;

б) від перехрестя Проспект Миру - вул. Шевченка до перехрестя Проспект Миру - вул. Симона Петлюри; в) від перехрестя Проспект Миру - вул. Симона Петлюри до перехрестя Проспект Миру вул. Міцкевича

Інтенсивності транспортних потоків на ділянках між перехрестями складають відповідно: вул. Проспект Миру - вул. Міцкевича складає 1850 авт./год; вул. Соборна - вул. В. Чорновола - вул. Міцкевича складає 1931 авт./год.; вул. Соборна - вул. Княгині Ольги - вул. Князя Володимира складає 1760 авт./год.; вул. Соборна - вул. Дубенська складає 1728 авт./год.

Найзавантажений і проблемний стосовно організації дорожнього руху є ділянки вулиць Проспекту Миру (мікрорайон Центральний). Хоча ділянка і має протяжність в 1 км, від вулиці Небесної Сотні до вулиці Міцкевича, проте нараховує 5 перехресть (рис. 4). Вулиці вказаної ділянки 3 двома смугами руху в кожному напрямку. Світлофорне регулювання здійснюється лише на перехрестях вулиць Небесної Сотні - Проспект Миру, вул. Набережна - Проспект Миру, вул. Симона Петлюри - Проспект Миру. Два інші нерегульовані перехрестя: вул. Шевченка - Проспект Миру, вул. Міцкевича - Проспект Миру. Проспект Миру є паралельним до вулиці Соборна, що в свою чергу розвантажує центральну частину міста від транспортних потоків.

Основне призначення координованого регулювання світлофорними об'єктами полягає у безупинному проїзді всіх транспортних засобів магістральними вулицями за принципом «зеленої хвилі, тобто досягається взаємоузгодження швидкості руху рухомого складу з фазами сигналів світлофорів.

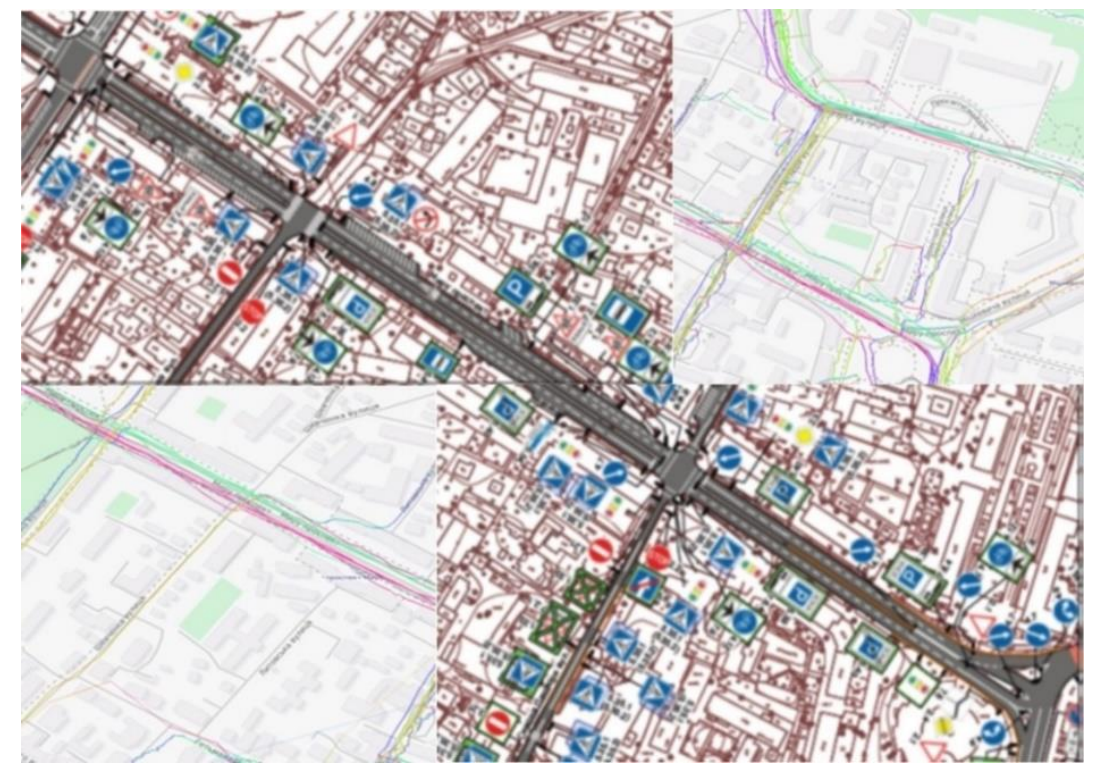

Рисунок 4 - Стан організації дорожнього руху на ділянках по вул. Проспекту Миру

Оптимальний цикл системи світлофорного регулювання з інтенсивністю потоку транспортних засобів 400-600 од./год. на смугу руху становить $[4,6,10]$

- $\quad 3$ двофазним регулюванням 


$$
T_{o}=\frac{2 L}{1-Y}
$$

- 3 багатофазним регулюванням

$$
T_{o}=\frac{1,5 L+5}{1-Y} .
$$

де $L$ - довжина перехрестя;

$Y$ - фазовий коефіцієнт перехрестя.

Ключовим і найскладнішим стосовно регулювання вважається перехрестя 3 максимальною розрахунковою тривалістю циклу (він приймається за основу для розрахунку інших перехресть). Тривалість основних тактів такого перехрестя обраховується за формулою $[4,6,10]$

$$
t_{\text {oc.K }}=\frac{y_{\text {iK }}}{Y_{\mathrm{K}}}\left(T_{o}-L\right)-1 \text {. }
$$

де $y_{\text {iк }}-$ фазовий коефіцієнт;

$Y_{\mathrm{K}}$ - фазовий коефіцієнт перехрестя.

Мінімальна розрахункова тривалість дозвільного зеленого сигналу світлофора неосновних напрямків руху (відповідно, червоного - на основному) $[4,6,10]$

$$
t_{\text {ДР. } \min }=\frac{y_{\text {ДР } T_{o}}}{Y}-1 \text {. }
$$

де $y_{д Р}-$ фазовий коефіцієнт дозвільного сигналу.

Максимальна розрахункова тривалість зеленого сигналу світлофора не ключових перехресть

$$
t_{\text {М.max }}=T_{o}-\left(t_{\text {ДР.min }}+t_{\text {ДП }}+\sum_{i=1}^{n} t_{\text {Ді }}\right),
$$

де $t_{\text {дп }}$-тривалість основного такту третьої фази;

$n$ - кількість фаз.

Ефективність координованого регулювання досягається при відстані між перехрестями до 700 метрів, оскільки збільшення відстані призводить до розпаду потоку транспортних засобів до чергового перехрестя.

Відстані перегонів між перехрестями Проспекту Миру - до 300 метрів: від перехрестя Проспект Миру - вул. Набережна до Проспект Миру - вул. Шевченка становить 170 м; від перехрестя Проспект Миру - вул. Шевченка до Проспект Миру - вул. Симона Петлюри становить 290 м; від перехрестя Проспект Миру - вул. Симона Петлюри до перехрестя Проспект Миру - вул. Міцкевича становить 270 метрів.

\begin{tabular}{|c|c|c|c|c|c|c|c|c|c|c|}
\hline \multirow[b]{2}{*}{ № } & \multirow[b]{2}{*}{$\begin{array}{c}\text { Назва } \\
\text { перехрестя }\end{array}$} & \multicolumn{7}{|c|}{ Розподіл часу в циклі } & \multirow[b]{2}{*}{ 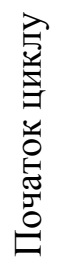 } & \multirow[b]{2}{*}{ 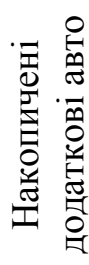 } \\
\hline & & 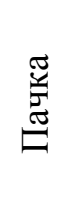 & 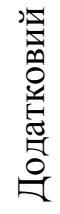 & 凅 & 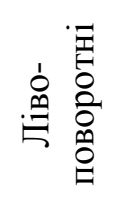 & $\begin{array}{l}\vec{P} \\
\text { : } \\
\text { : }\end{array}$ & 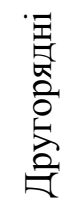 & 点 & & \\
\hline \multicolumn{11}{|c|}{ Прямий напрям } \\
\hline 1 & Набережна & 11 & 0 & 12 & 14 & 29 & 14 & 60 & 0 & 0 \\
\hline 2 & Шевченка & 25 & 9 & 26 & 14 & 43 & 14 & 60 & 8 & 5 \\
\hline 3 & С. Петлюри & 22 & 6 & 23 & 14 & 40 & 14 & 60 & 26 & 7 \\
\hline 4 & Міцкевича & 17 & 6 & 18 & 14 & 35 & 22 & 60 & 41 & 9 \\
\hline \multicolumn{11}{|c|}{ Зворотній напрям } \\
\hline 4 & Міцкевича & 19 & 0 & 18 & 14 & 35 & 22 & 60 & 41 & 0 \\
\hline 3 & С. Петлюри & 19 & 9 & 20 & 14 & 37 & 14 & 60 & 49 & 5 \\
\hline 2 & Шевченка & 17 & 6 & 18 & 14 & 35 & 14 & 60 & 12 & 7 \\
\hline 1 & Набережна & 17 & 6 & 18 & 14 & 35 & 14 & 60 & 24 & 9 \\
\hline
\end{tabular}

Практично на всій протяжності вулиці Проспект Миру спостерігається висока інтенсивність руху транспортних засобів, яка спричиняє транспортні затримки і потребує узгодження роботи світлофорного регулювання (табл. 1).

Таблиця 1 - Розподіл часу в циклі

«Стійкість» світлофорного координування руху перехресть полягає у забезпеченні єдиної світлофорної сигналізації за однаковими встановленими фазовими зсувами 3 врахуванням особливостей транспортного потоку (нерівномірності руху транспорту, їх швидкості, можливого випередження, обгонів, завдяки різному складу транспортних засобів у потоці, впливу дорожніх умов тощо). 
В універсальних системах координованого регулювання фазовий зсув для перехресть співставний 3 відстанню між ними і швидкістю координації на кожному перегоні. Системи координованого регулювання «зелена хвиля», хоча і більш складні апаратно, але вони ефективніші.

В основі режимів роботи світлофорних об'єктів для умов координованого регулювання використано трьох фазне світлофорне регулювання. Результати аналітичних оцінок затримок в прямому та зворотному напрямках (без координації та 3 координацією, для кожного напрямку) наведено в таблицях 2-3.

Таблиця 2 - Аналітична оцінка затримок (без координації)

\begin{tabular}{|c|c|c|c|c|c|c|c|c|c|c|c|c|}
\hline \multirow[b]{2}{*}{ Напрям } & \multicolumn{3}{|c|}{$\begin{array}{l}\text { Рівень завантаження } \\
\text { для існуючих циклів }\end{array}$} & \multicolumn{3}{|c|}{$\begin{array}{c}\text { Затримка без } \\
\text { координації, с }\end{array}$} & \multicolumn{3}{|c|}{$\begin{array}{c}\text { Рівень завантаження для } \\
\text { оптимальних циклів }\end{array}$} & \multicolumn{3}{|c|}{$\begin{array}{c}\text { Затримка без } \\
\text { координації, с }\end{array}$} \\
\hline & 鴶 & 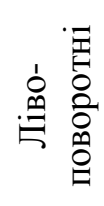 & 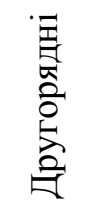 & 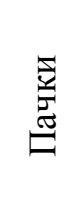 & 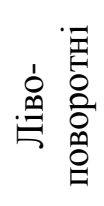 & 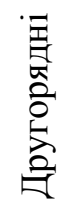 & 胥 & 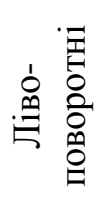 & 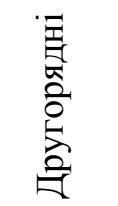 & 莺 & 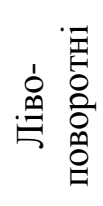 & 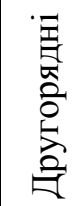 \\
\hline \multicolumn{13}{|c|}{ Прямий напрям } \\
\hline Набережна & 0,19 & 0 & 0,16 & 8,2 & 0 & 7,9 & 0,20 & 0 & 0,16 & 5,6 & 0 & 5,3 \\
\hline Шевченка & 0,29 & 0 & 0,16 & 8,1 & 0 & 9.0 & 0,31 & 0 & 0,17 & 6,1 & 0 & 6,1 \\
\hline Петлюри & 0,26 & 0 & 0,19 & 7,7 & 0 & 9,2 & 0,25 & 0 & 0,21 & 5,1 & 0 & 8,1 \\
\hline Міцкевича & 0,20 & 0 & 0,34 & 8,4 & 0 & 9,3 & 0,40 & 0,18 & 0,36 & 20,8 & 17,4 & 11,5 \\
\hline \multicolumn{13}{|c|}{ Зворотній напрям } \\
\hline Набережна & 0,31 & 0 & 0,16 & 9,4 & 0 & 7,9 & 0,33 & 0 & 0,16 & 6,7 & 0 & 5,3 \\
\hline Шевченка & 0,27 & 0 & 0,16 & 7,9 & 0 & 9,0 & 0,29 & 0 & 0,17 & 6,0 & 0 & 6,1 \\
\hline Петлюри & 0,29 & 0 & 0,19 & 8,1 & 0 & 9,2 & 0,27 & 0 & 0,21 & 5,4 & 0 & 8,1 \\
\hline Міцкевича & 0,39 & 0 & 0,34 & 9,9 & 0 & 9,3 & 0,77 & 0 & 0,36 & 34,0 & 0 & 11,5 \\
\hline
\end{tabular}

Таблиця 3 - Аналітична оцінка затримок (з координацією)

\begin{tabular}{|c|c|c|c|c|c|c|c|c|c|c|c|c|}
\hline \multicolumn{7}{|c|}{ Однаковий час в циклі, с. } & \multicolumn{3}{|c|}{$\begin{array}{c}\text { Рівень завантаження } \\
\text { для координації }\end{array}$} & \multicolumn{3}{|c|}{$\begin{array}{c}\text { Затримка } 3 \\
\text { координацією, с }\end{array}$} \\
\hline 莺 & 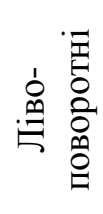 & 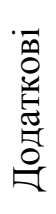 & 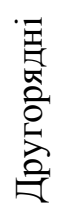 & 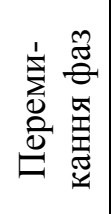 & 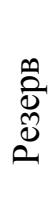 & $\begin{array}{l}0 \\
0 \\
0 \\
0 \\
0\end{array}$ & 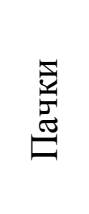 & 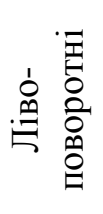 & 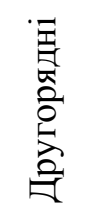 & 鴶 & 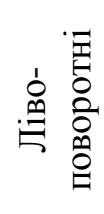 & 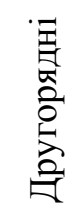 \\
\hline \multicolumn{13}{|c|}{ Прямий напрям } \\
\hline 11 & 14 & 0 & 14 & 7 & 14 & 60 & 0,47 & 0,29 & 0,31 & 24 & 18,7 & 18,9 \\
\hline 16 & 14 & 9 & 14 & 7 & 0 & 60 & 0,47 & 0,03 & 0,30 & 0,9 & 16,2 & 18,8 \\
\hline 15 & 14 & 6 & 14 & 7 & 3 & 60 & 0,47 & 0,29 & 0,34 & 0,9 & 18,6 & 19,3 \\
\hline 11 & 14 & 6 & 22 & 7 & 0 & 60 & 0,47 & 0,18 & 0,43 & 0,9 & 17,5 & 14,8 \\
\hline \multicolumn{11}{|c|}{ Час затримки за прямим напрямом } & 11,1 & 9,5 \\
\hline \multicolumn{13}{|c|}{ Зворотній напрям } \\
\hline 10 & 14 & 6 & 14 & 7 & 8 & 60 & 0,69 & 0 & 0,31 & 31,3 & 0 & 18,9 \\
\hline 10 & 14 & 6 & 14 & 7 & 9 & 60 & 0,69 & 0 & 0,30 & 0,9 & 0 & 18,8 \\
\hline 10 & 14 & 9 & 14 & 7 & 6 & 60 & 0,69 & 0,08 & 0,34 & 0,9 & 16,6 & 19,3 \\
\hline 17 & 14 & 0 & 22 & 7 & 0 & 60 & 0,64 & 0 & 0,43 & 0,9 & 0 & 14,8 \\
\hline \multicolumn{11}{|c|}{ Час затримки за зворотнім напрямом } & 7,91 & 7,3 \\
\hline
\end{tabular}

\section{ОБГОВОРЕННЯ РЕЗУЛЬТАТІВ ДОСЛІДЖЕННЯ}

Вихідними даними для побудови системи світлофорного регулювання є оцінка в реальному часі пропускної здатності транспортного потоку вулично-дорожньої мережі 3 врахуванням змодельованої поведінки пішоходів.

За критерій оптимізації світлофорного регулювання приймається показник середньої транспортної затримки (різниця між фактичним часом проїзду регульованого і нерегульованого перехрестя). 
Як один із варіантів зменшення транспортної затримки досягається шляхом координування світлофорного регулювання перехресть за принципом «зеленої хвилі».

\section{ВИСНОВКИ}

Дієвим заходом покращення системи організацій дорожнього руху досягається узгодженням роботи світлофорних об'єктів завдяки їх координуванню за принципом «зеленої хвилі» для безперешкодного проїзду перехресть.

Запропоновано проект удосконалення руху на вулиці Проспект Миру в м. Рівне. В ході обстеження дорожніх умов, інтенсивності та складу транспортних потоків, проведених аналітичних розрахунків змодельоване координоване світлофорне регулювання ділянки перехресть Проспекту Миру.

Доцільність впровадження заходів $є$ виправданим, оскільки вони сприяють збільшенню пропускної здатності транспортних засобів, зменшують їх накопичення на перехрестях у п'ять разів, скорочують час проїзду проблемних ділянок у два рази, а також покращать екологічну ситуацію в центральній частині міста.

\section{ПЕРЕЛІК ДЖЕРЕЛ ПОСИЛАННЯ}

1. Грицунь О. М. Обгрунтування раціональних режимів світлофорного регулювання 3 урахуванням характеристик транспортних потоків і поведінки пішоходів : дис. ... канд. тех. наук : 05.22.01 / Національний університет «Львівська політехніка». Львів, 2019. 167 с.

2. Грицунь О. М. Аналіз поведінки пішоходів на регульованих перехрестях. Міжвузівський збірник «Наукові нотатки». 2016. Вип. 55. С. 90-95.

3. Організація та регулювання дорожнього руху : підручник / О. О. Бакуліч та ін. ; за заг. ред. В. П. Поліщука. Київ : Знання України, 2012. 467 с.

4. Поліщук В. П., Дзюба О. П. Теорія транспортного потоку : методи та моделі організації дорожнього руху. Київ : Знання України, 2008. 175 с.

5. Krystopchuk M. Change of drivers functional condition while moving along highways of different technical categories. Transport technologies. 2020. Vol. 1. № 1. pp. 22-32.

6. Системологія на транспорті. Організація дорожнього руху: кн. 4 / Гаврилов Е. В. та ін.; за заг. ред. М. Ф. Дмитриченка. Київ : Знання України, 2005. 452 с.

7. Пашкевич С. М., Кристопчук М. Є. Аналіз параметрів функціонування об’єктів транспортної інфраструктури на формування транспортних та пасажирських потоків у містах. Сучасні технологї̈ 8 машинобудуванні та транспорті. 2018. № 1. С. 66-72.

8. Гілевич В. В. Підвищення ефективності роботи регульованих перехресть 3 жорсткими світлофорними циклами : дис. ... канд. тех. наук : 05.22.01 / Національний Університет «Львівська Політехніка». Львів, 2016. 169 с.

9. Formation and Distribution Flows of External Transport in the City / Krystopchuk, M., Pashkevych, S., Khitrov, I., Tkhoruk, Y. International Conference on Reliability and Statistics in Transportation and Communication. 2019. Springer, Cham. pp. 141-150.

10. Єресов В. І., Христенко О. В. Комплексна оцінка ефективності світлофорного регулювання на перехрестях. Вісник Національного транспортного університету. 2009. № 19, Ч. 2. С. $72-77$.

11. Капский Д. В. Навой Д. В. Методика определения экономических потерь при координированном регулировании движения транспортных и пешеходных потоков. Вестник БНТУ.2010. № 4. C. 60-70.

12. Cheng D. X. Zong T. Z., Messer C. J. Development of an Improved Cycle Length Model over the Highway Capacity Manual 2000 Quick Estimation Method. Journal of Transportation Engineering. 2005. № 12. P. 890-897.

13. Трушевський В. Е. Удосконалення світлофорного регулювання при організації руху за окремими напрямками : дис. ... канд. тех. наук: 05.22.01 / Національний транспортний університет. Київ. 2016. 150 с.

14. Guo H. Reliability analysis of pedestrian safety crossing in urban traffic environment. Safety Science. 2012. Vol. 50, Issue 4. P. 968-973. http://dx.doi.org/10.1016/j.ssci.2011.12.027

15. Noland R. Pedestrian travel times and motor vehicle traffic signals. Transportation Research Record: Journal of the Transportation Research Board. 1996. T. 1553. №. 1. C. $28-33$. http://dx.doi.org/10.3141/1553-04. 


\section{REFERENCES}

1. Hrytsun O. M. (2019). Obgruntuvannia ratsionalnykh rezhymiv svitlofornoho rehuliuvannia $z$ urakhuvanniam kharakterystyk transportnykh potokiv i povedinky pishokhodiv : dys. ... kand. tekh. nauk : 05.22.01 / Natsionalnyi universytet «Lvivska politekhnika». Lviv, 147.

2. Hrytsun O. M. (2016). Analiz povedinky pishokhodiv na rehulovanykh perekhrestiakh. Mizhvuzivskyi zbirnyk «Naukovi notatky», 55, 90-95.

3. Polishchuk V. P. (Eds.). (2012). Orhanizatsiia ta rehuliuvannia dorozhnoho rukhu. Kyiv : Znannia Ukrainy, 467.

4. Polishchuk V. P., \& Dziuba O. P. (2008). Teoriia transportnoho potoku : metody ta modeli orhanizatsii dorozhnoho rukhu. Kyiv : Znannia Ukrainy, 175.

5. Krystopchuk M. (2020). Change of drivers functional condition while moving along highways of different technical categories. Transport technologies. Vol. 1, № 1, 22-32.

6. Dmytrychenko M. F. (Eds.) (2005). Systemolohiia na transporti. Orhanizatsiia dorozhnoho rukhu: kn. 4. Kyiv : Znannia Ukrainy, 452.

7. Pashkevych S. M., \& Krystopchuk M. Ye. (2018). Analiz parametriv funktsionuvannia obiektiv transportnoi infrastruktury na formuvannia transportnykh ta pasazhyrskykh potokiv u mistakh. Suchasni tekhnolohii v mashynobuduvanni ta transporti. 1, 66-72.

8. Hilevych V. V. (2016). Pidvyshchennia efektyvnosti roboty rehulovanykh perekhrest z zhorstkymy svitlofornymy tsyklamy : dys. ... kand. tekh. nauk : 05.22.01 / Natsionalnyi Universytet «Lvivska Politekhnika». Lviv, 169.

9. Krystopchuk M., Pashkevych S., Khitrov I., \& Tkhoruk Y. (2019). Formation and Distribution Flows of External Transport in the City. International Conference on Reliability and Statistics in Transportation and Communication, 141-150.

10. Yeresov V. I., \& Khrystenko O. V. (2009). Kompleksna otsinka efektyvnosti svitlofornoho rehuliuvannia na perekhrestiakh. Visnyk Natsionalnoho transportnoho universytetu, 19, 72-77.

11.Kapskyi D. V., \& Navoi D. V. (2010). Metodyka opredelenyia ekonomycheskykh poter pry koordynyrovannom rehulyrovanyy dvyzhenyia transportnykh y peshekhodnykh potokov. Vestnyk BNTU, 4, $60-70$.

12. Cheng D. X. Zong T. Z., \& Messer C. J. (2005). Development of an Improved Cycle Length Model over the Highway Capacity Manual 2000 Quick Estimation Method. Journal of Transportation Engineering, 12, 890-897.

13. Trushevskyi V. E. (2016). Udoskonalennia svitlofornoho rehuliuvannia pry orhanizatsii rukhu za okremymy napriamkamy : dys. ... kand. tekh. nauk: 05.22.01 / Natsionalnyi transportnyi universytet. Kyiv, 150.

14. Guo H. (2012). Reliability analysis of pedestrian safety crossing in urban traffic environment. Safety Science. Vol. 50, Issue 4, 968-973. http://dx.doi.org/10.1016/j.ssci.2011.12.027

15. Noland R. (1996). Pedestrian travel times and motor vehicle traffic signals. Transportation Research Record: Journal of the Transportation Research Board, T. 1553, №. 1, 28-33. http://dx.doi.org/10.3141/1553-04.

\footnotetext{
M. Krystopchuk, I. Khitrov, O. Tson, O. Pochuzhevskiy. Research of coordinated management of transport flows in the central part of the city.

Problems related to the deterioration of the functioning of the road network significantly affect the operation of the entire transport complex of the city. Traffic delays, congestion, characterized by increased travel time, deterioration of transport services, increased pollution of the urban environment due to increased emissions and noise, an increase in the number of accidents indicate a mismatch of traffic capacity on the road network of cities to the modern level of motorization. The greatest difficulties with the rational organization of traffic arise at intersections, as they are "bottlenecks" in the road network in terms of efficient and safe maintenance of traffic and pedestrian flows. To control traffic at intersections, traffic lights are most often used, which can increase road safety, reduce delays, reduce energy consumption and negatively affect the environment, which in turn has a significant impact on the quality of life in cities.

When creating conditions for optimizing the operation of regulated intersections, it is necessary to take into account the technical condition of vehicles, the condition of the road surface and technical means of traffic regulation. Reducing travel time, minimizing financial and material costs, ensuring the safety of cars and pedestrians, comfort and convenience when traveling are the main requirements for the functioning of the road network and transport infrastructure. In many cases, the intensity of traffic exceeds the capacity of
} 
the street and road network, so it is important to increase the efficiency of its operation with the lowest capital costs.

The paper considers the results of the study of the impact of coordinated traffic management in the central part of the city of Rivne on the reduction of traffic delays when passing intersections by vehicles and offers technical solutions to improve road safety by equipping intersections with additional technical means of traffic control.

Key words: traffic intensity, traffic flow composition, coordinated control, saturation flow, adjustable intersection, traffic light control cycle.

КРИСТОПЧУК Михайло Свгенович, кандидат технічних наук, доцент, завідувач кафедри транспортних технологій і технічного сервісу, Національний університет водного господарства та природокористування, e-mail: m.ie.krystopchuk@nuwm.edu.ua; https://orcid.org/0000-0002-8701-4469;

ХІТРОВ Ігор Олександрович, кандидат технічних наук, доцент, доцент кафедри транспортних технологій i технічного сервісу, Національний університет водного господарства та природокористування, e-mail: i.o.khitrov@ nuwm.edu.ua; https://orcid.org/0000-0003-2310-1472;

ЦЬОНЬ Олег Петрович, кандидат технічних наук, доцент кафедри автомобілів, Тернопільський національний технічний університет імені Івана Пулюя, e-mail: tsonoleg@gmail.com; https://orcid.org/0000-0003-1056-4697;

ПОЧУЖЕВСЬКИЙ Олег Дмитрович, кандидат технічних наук, доцент кафедри автомобільного транспорту, Криворізький національний університет, e-mail: aaxforever@gmail.com; https://orcid.org/0000-0002-7347-3752.

Mykhailo KRYSTOPCHUK, PhD, Associate Professor, Head of the Transport Technologies and Technical Service Department, National University of Water and Environmental Engineering, e-mail: m.ie.krystopchuk@nuwm.edu.ua; https://orcid.org/0000-0002-8701-4469;

Ihor KHITROV, PhD, Associate Professor of the Transport Technologies and Technical Service Department, National University of Water and Environmental Engineering, e-mail: i.o.khitrov@nuwm.edu.ua; https://orcid.org/0000-0003-2310-1472;

Oleg TSON, PhD, Associate Professor of the Automobiles Department, Ternopil Ivan Puluj National Technical University, e-mail: tsonoleg@gmail.com; https://orcid.org/0000-0003-1056-4697;

Oleg POCHUZHEVSKIY, PhD, Associate Professor of the Motor Transport Department, Kryvyi Rih National University, e-mail: aaxforever@gmail.com; https://orcid.org/0000-0002-7347-3752

DOI 10.36910/automash.v1i16.511 